\title{
Oppimisympäristö bioenergia-alan osaamisen kehittymisen tukena
}

\author{
Ari Sivula \\ Seinäjoen ammattikorkeakoulu, Maa- ja metsätalouden yksikkö, Tuomarniementie 55, 63700 Ähtäri \\ Ari.Sivula@seamk.fi
}

\section{Tiivistelmä}

Energia-ala on tällä hetkellä nopeasti kehittyvä. Uusiutuvien energialähteiden merkitys korostuu muun muassa fossiilisten polttoaineiden vähentyessä. EU on sitoutunut kasvattamaan uusiutuvien energialähteiden osuutta kokonaisenergian kulutuksesta 20 prosenttiin vuoteen 2020 mennessä. Suomessa uusiutuvien energialähteiden osuutta tulisi kasvattaa 38 prosenttiin. Tämä aiheuttaa uusia haasteita bioenergia-alan yrittäjille sekä muille energia-alan toimijoille. Alan kehittyessä uutta tietoa tulisi pystyä välittämään uusin innovatiivisin menetelmin alan toimijoille.

Bioenergia-asiantuntijuuden kehittäminen työelämälähtöisesti -hanke aloitettiin vuonna 2009 ja se jatkuu vuoden 2012 lokakuuhun saakka. Hanke on ESR-rahoitteinen, jonka lisäksi valtio ja kohdekunnat sekä Seinäjoen ammattikorkeakoulu rahoittavat hanketta. Hankkeen yksi keskeinen tavoite on kehittää työelämälähtöinen oppimisympäristö bioenergia-alalle. Ympäristölle asetettiin erilaisia tavoitteita, joita olivat muun muassa nopea tiedon välitys alan toimijoille, bioenergia-alan profiilin nostaminen sekä sähköinen rajapinta työelämän ja korkeakoulutuksen välille. Lisäksi oppimisympäristön tulee rakentua yleisen käytön vuoksi avoimen lähdekoodin alustoille.

Oppimisympäristö tukee bioenergia-alan kehittymistä eri tavoin. Oppimisympäristöön on kerätty tietoa, joka auttaa alan toimijoita kehittämään toimintaansa. Lisäksi se tarjoaa työkalut, jolla vauhditetaan yhteistyötä bioenergiatoimijoiden välillä. Toimijoiden on mahdollista hyödyntää työkaluja eri tavoin, esimerkiksi erilaisissa neuvottelutilanteissa. Oppimisympäristö toimii julkaisukanavana uudelle tiedolle, jolloin tiedon jalkauttaminen on alan toimijoille nopeampaa.

\section{Asiasanat}

Bioenergia, oppimisympäristö, uusiutuva energia

Seamk tutkimus- ja kehittämispalvelut SEINÄJOEN AMMATTIKORKEAKOULU
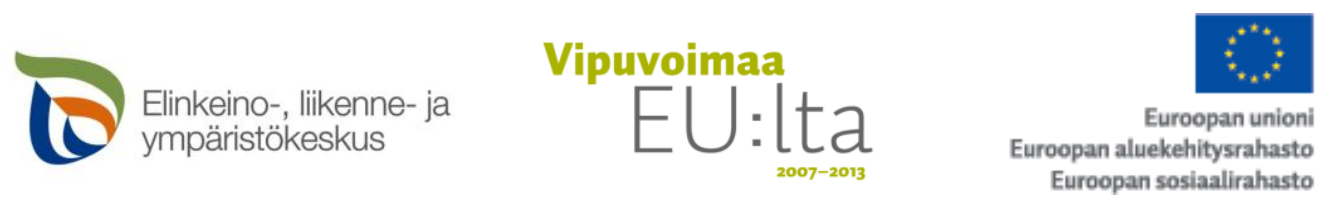


\section{Johdanto}

Energia-ala on yksi nopeimmin kehittyvistä aloista. Uusiutuvien energialähteiden merkitys korostuu muun muassa fossiilisten polttoaineiden vähentyessä. EU on sitoutunut kasvattamaan uusiutuvien energialähteiden osuutta kokonaisenergian kulutuksesta 20 prosenttiin vuoteen 2020 mennessä (Ministry of Employment and the Economy 2011). Suomessa uusiutuvien energialähteiden osuutta tulisi kasvattaa 38 prosenttiin (Ministry of Employment and the Economy 2011). Tämä aiheuttaa uusia haasteita muun muassa energia-alan yrittäjille sekä muille energia-alan toimijoille. Alan kehittyessä uutta tietoa tulisi pystyä välittämään uusin innovatiivisin menetelmin alan toimijoille.

Nykypäivänä oppimisympäristöjä hyödynnetään laajasti korkeakouluissa ja muissa oppilaitoksissa, mutta yrityksissä niiden hyödyntäminen on vähäisempää ja tämä näkyy esimerkiksi pk-sektorilla. Oppimisympäristöt ovat yksi ratkaisu yritysten henkilöstön kouluttamiseen, koska kyseessä on ajasta ja paikasta riippumaton oppimistapa.

Bioenergia-asiantuntijuuden kehittäminen työelämälähtöisesti -hanke aloitettiin vuonna 2009 ja se jatkuu vuoden 2012 lokakuuhun saakka. Hanke on ESR-rahoitteinen, jonka lisäksi valtio ja kohdekunnat sekä Seinäjoen ammattikorkeakoulu rahoittavat hanketta. Hankkeen yksi keskeinen tavoite on kehittää työelämälähtöinen oppimisympäristö bioenergia-alalle (ESR-projektisuunnitelma 2009). Ympäristölle asetettiin erilaisia tavoitteita, joita olivat muun muassa nopea tiedon välitys bioenergia-alan toimijoille, bioenergiaalan profiilin nostaminen sekä sähköinen rajapinta työelämän sekä korkeakoulutuksen välille. Lisäksi oppimisympäristön tulee rakentua yleisen käytön vuoksi avoimen lähdekoodin (engl. Open Source) alustoille.

\section{Oppimisympäristö}

Oppimisympäristö voi olla joko fyysinen (engl. Physical Learning Enviroment) tai virtuaalinen (engl. Virtual Learning Environment). Fyysinen oppimisympäristö on tila, missä opetus fyysisesti tapahtuu, esimerkiksi luokkahuone tai laboratorio (Scholastic 2011). Fyysinen oppimisympäristö voi olla myös demola, jossa demostroidaan laitteen tai laitoksen, kuten lämpölaitoksen, toimintaa.

Tässä tutkimuksessa perehdytään virtuaalisen oppimisympäristön hyödyntämiseen bioenergia-alalla. Virtuaaliset oppimisympäristöt on nähty olevan etäoppimisen mahdollistava työkalu (Greasley 2004: 975). Tällä tavoin kasvotusten tehdyt kontaktit vähenevät ohjaajan kanssa. Oppiminen on myös erilaista kuin perinteinen oppiminen. Virtuaaliset oppimisympäristöt soveltuvat työelämälähtöisiksi oppimisympäristöiksi, koska työelämässä on vähemmän aikaa varsinaiselle opiskelulle. Oikein hyödynnettynä virtuaaliset oppimisympäristöt mahdollistavat ajasta ja paikasta riippumattoman opiskelun.

Bioenergia-alan oppimisympäristö rakentuu kolmesta eri kokonaisuudesta sekä niiden välisistä yhteyksistä. Oppimisympäristökokonaisuus ei ole yksittäinen ympäristö vaan kokoelma eri ympäristöjä, jotka ovat saumattomassa yhteydessä toisiinsa. Henkilön käyttäessä oppimisympäristöä hän ei erota, mitä osaaluetta hän kulloinkin hyödyntää. Tämä helpottaa oppimisympäristön omaksumista ja käyttöä. Kuva 1 esittää oppimisympäristömallia sekä ympäristöjen välisiä yhteyksiä. 


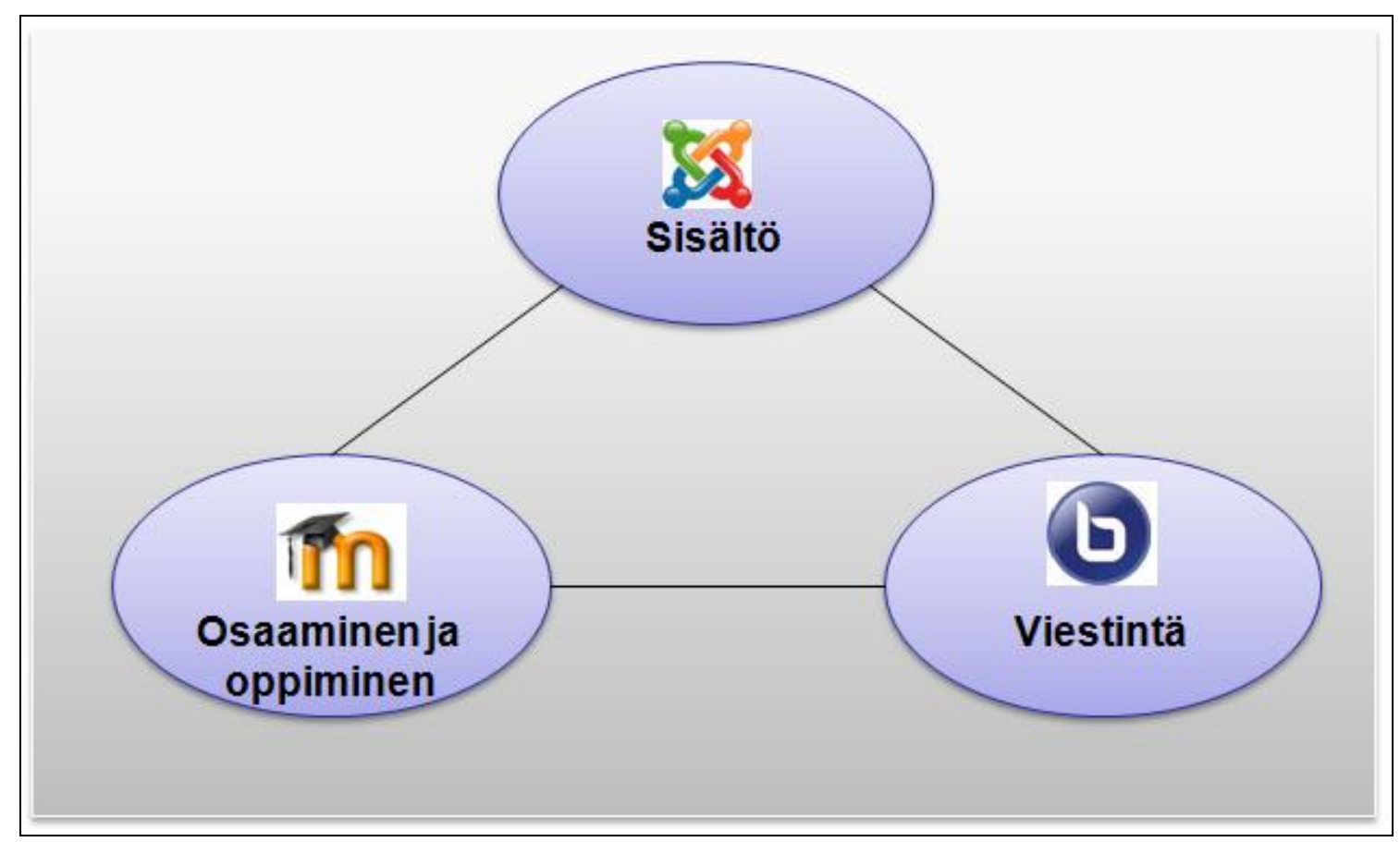

Kuva 1. Oppimisympäristömalli (Sivula 2011)

Bioenergia-alan oppimisympäristö rakentuu sisällöllisen, osaamisen ja oppimisen sekä viestinnän osaalueista. Oppimisympäristön sisällöllinen osa-alue sisältää muun muassa yleistietoa bioenergiasta, sen mahdollisuuksista, hankkeista, koulutuksesta sekä bioenergia-alan tapahtumista. Kyseessä on yleinen osaalue, josta on hyötyä sekä alan toimijoille että bioenergiasta kiinnostuneille tahoille. Sisällöllisen osaalueen ympäristöksi valikoitui selkeytensä vuoksi Joomla, josta on saatavilla lisätietoa ympäristön verkkosivuilta (Joomla! 2001). Sisällöllinen osa-alue toimii myös liittymänä, jota henkilö käyttää ensimmäisenä astuessaan oppimisympäristöön.

Osaamisen ja oppimisen osa-alue sisältää itseopiskelukokonaisuuksia, joita on mahdollista hyödyntää sekä yrityksissä että korkeakouluopetuksessa. Itseopiskelupaketit on pyritty toteuttamaan siten, että ne olisivat kaikkien hyödynnettävissä. Osaamisen ja oppimisen osa-alueen alustaksi valikoitui yksi eniten käytetyistä virtuaalisista oppimisympäristöistä. Moodle-ympäristöstä on saatavissa lisätietoa sen verkkosivuilta (Moodle 2011).

Viestinnällinen osa-alue sisältää työkalut nopeaan viestintään. Oppimisympäristössä tämä ilmenee muun muassa videoneuvottelun sekä erilaisten keskustelualustojen muodossa, joista yksi esimerkki ovat sosiaalisen median työkalut, Facebook ja Youtube. Videoneuvottelua on mahdollista hyödyntää muun muassa yritysten ja koulutusorganisaatioiden kehittämishankkeissa sekä muissa toimissa. Oppimisympäristön videoneuvotteluympäristöksi valikoitui helppokäyttöisyytensä vuoksi BigBlueButton, josta on saatavissa lisätietoa ympäristön verkkosivuilta (BigBlueButton 2011).

\section{Oppimisympäristön testaus sekä tulokset}

Oppimisympäristön pohja rakennettiin hanketoimijoiden ja -kehittäjien toimesta. Oppimisympäristöä testattiin ja pilotoitiin bioenergia-alan toimijoilla. Testiryhminä olivat yrittäjät, opiskelijat, opettajat sekä 
tutkijat. Testiin osallistui yhteensä 27 koehenkilöä, jotka arvioivat oppimisympäristön käytettävyyttä sekä hyödyllisyyttä. Testimetodina oppimisympäristötestissä hyödynnettiin harmaalaatikkotestausta (engl. Gray Box Testing), jossa yhdistyvät mustalaatikko- (engl. Black Box Testing) ja lasilaatikkotestaus (engl. Glass Box Testing) (Haikala \& Märijärvi 2004: 291).

Mustalaatikkotestauksessa testitapaukset valitaan testattavan ohjelman spesifikaatioiden perusteella tutustumatta ohjelman toteutukseen (Haikala \& Märijärvi 2004: 291). Lasilaatikkotestauksessa testitapausten valinnassa käytetään hyväksi tietoa ohjelman toteutuksesta (Haikala \& Märijärvi 2004: 291). Harmaalaatikkotestaus tarkastelee kokonaisuutta, jolloin se soveltuu hyvin verkkopohjaisten ympäristöjen testausmetodiksi.

Oppimisympäristö rakentuu eri osista, jonka vuoksi koehenkilöiden oli mahdollista tarkastella ympäristöä eri näkökulmista. Esimerkiksi yrittäjät tarkastelevat ympäristöä eri tavoin kuin opiskelijat. Tämä on havaittavissa myös testauksista saaduista tuloksista. Oppimisympäristössä hyödynnetään myös sosiaalista mediaa, joka oli suurin mielipiteiden jakaja testeissä. Osa koehenkilöistä koki sosiaalisen median työkalut hyödylliseksi ja osa taas ei.

Testeissä mukana olleet henkilöt kokevat, että tämän tyylisestä oppimisympäristöstä on hyötyä bioenergia-alalla. Kyseessä on ensimmäinen tämän tyylinen bioenergia-alan oppimisympäristö, jossa yrittäjät sekä muut bioenergia-alan toimijat kohtaavat. Oppimisympäristö yhdistää sekä työkalut että bioenergiatiedon. Suurin osa koehenkilöistä kokee, että oppimisympäristö on helppokäyttöinen ja sen sisältävät työkalut ovat hyödyllisiä.

Suurin osa koehenkilöistä kokee, että oppimisympäristön itseopiskelupaketit ovat hyödyllisiä. Esimerkkinä itseopiskelupaketeista on metsäenergiapohjainen opintopolku, jossa yhdistyvät sekä virtuaalinen että fyysinen oppiminen (EP-energia 2011). Itseopiskelupaketit on rakennettu siten, että niitä on mahdollista hyödyntää joko kokonaisuudessaan tai osittain.

Testeissä kävi ilmi, että tämän tyylisen ympäristön työkalut soveltuvat paremmin pk-yrityksille, koska isoilla yrityksillä on lähes poikkeuksetta omat työkalut toimintansa tukena. Oppimisympäristössä oleva tieto nähtiin hyödylliseksi kaiken suuruisille yrityksille. Tiedon lisäksi oppimisympäristössä tulisi olla paljon kuvia ja videoita, sillä oppiminen koetaan niistä helpommaksi.

Tarkemmat tulokset testeistä ovat luettavissa hankkeen kotisivuilta (Seamk 2011).

\section{Pohdinta ja johtopäätökset}

Testeihin ja pilotointiin perustuen virtuaalinen oppimisympäristö soveltuu bioenergia-alalle. Bioenergiaalalla yksi haaste on uuden tutkimustiedon jalkauttaminen alan yrityksiin. Virtuaalinen oppimisympäristö on tiedon jakamiseen yksi ratkaisu. Virtuaalisilla oppimisympäristöillä on mahdollista nopeuttaa tiedon jakamista, koska kyseessä on ajasta ja paikasta riippumaton opiskelumahdollisuus. Kaikki oppimisympäristöt vaativat opiskelua ja uuden oppimista, jotta käyttö olisi mahdollista. Oppimisympäristöistä tulisi näin ollen tehdä mahdollisimman helppokäyttöisiä, jolloin niiden omaksuminen olisi nopeampaa ja helpompaa.

Oppimisympäristö tukee bioenergia-alan kehittymistä. Oppimisympäristöön on kerätty tietoa, joka auttaa alan toimijoita kehittämään toimintaansa. Lisäksi oppimisympäristö tarjoaa työkalut, jolla vauhditetaan 
yhteistyötä bioenergia-alan toimijoiden välillä. Toimijoiden on mahdollista hyödyntää työkaluja eri tavoin, josta esimerkkinä neuvottelutilanne.

Oppimisympäristö toimii julkaisukanavana uudelle tiedolle, jolloin jakautuminen on tiedon osalta nopeaa. Iso haaste oppimisympäristön kohdalla on tiedon ylläpito hankkeen päättymisen jälkeen. Ympäristössä oleva tieto vanhenee, jonka vuoksi se tarvitsee ylläpitoa. Ratkaisuna tähän voisi olla ylläpidon hajauttaminen sekä yrityksiin että muille energia-alan toimijoille. Oppimisympäristöjen hyödyntäminen vaatii osaamista, jonka nuoret oppivat jo opintojensa alkuvaiheessa. Vanhempi väestö ei tällaista koulutusta ole useinkaan saanut, jonka vuoksi tarvitaan pohjakoulutusta myös oppimisympäristöjen käytöstä.

\section{Lähteet}

BigBlueButton. 2011. BigBlueButton-verkkosivusto. Viitattu 4.11.2011. Saatavilla World Wide Webistä <URL: http://bigbluebutton.org/>

EP-energia. 2011. Etelä-Pohjanmaan energia -oppimisympäristö. Viitattu 7.11.2011. Saatavilla World Wide Webistä <URL: http://www.ep-energia.fi/>

ESR-projektisuunnitelma. 2009. Bioenergia-asiantuntijuuden kehittäminen työelämälähtöisesti ESRhankkeen projektisuunnitelma.

Greasley, K. 2004. A virtual learning environment for operations management: Assessing the student's perspective. Teoksessa: International Journal of Operations \& Production Management; 2004; 24, 9/10; ProQuest: 974 s.

Haikala, I. \& Märijärvi J. 2004. Ohjelmistotuotanto. ISBN 952-14-0850-2.

Joomla!. 2011. Joomla!-verkkosivusto. Viitattu 4.11.2011. Saatavilla World Wide Webistä <URL: http://www.joomla.org/>

Ministry of Employment and the Economy. 2011. Energy. Viitattu 1.11.2011. Saatavilla World Wide Webistä <URL: http://www.tem.fi/index.phtml?l=en\&s=2070>

Moodle. 2011. Moodle-verkkosivusto. Viitattu 4.11.2011. Saatavilla World Wide Webistä <URL: http://moodle.org/>

Scholastic. 2011. Classroom Organization: The Physical Environment. Viitattu 3.11.2011. Saatavilla World Wide Webistä <URL: http://www.scholastic.com/teachers/article/classroom-organizationphysical-environment>

Seamk. 2011. Bioenergia-asiantuntijuuden kehittäminen työelämälähtöisesti -hanke. Viitattu 11.11.2011. Saatavilla World Wide Webistä <URL:

http://www.seamk.fi/Suomeksi/SeAMK_Info/Yksikot/SeAMK_Maa-_ja_metsatalous/Tutkimus_ja_kehittamistoiminta/Bioenergia-asiantuntijuuden_kehittaminen_tyoelamalahtoisesti.iw3> 